\title{
Arba'in dar Būšehr. 1 CD avec livret de présentation (persan et anglais) rédigé par Fowziye Majd, M.CD-217, Tehrān, Māhūr, 2006. [Arba'inn à Bushehr]
}

\section{Sāsān Fāțemī}

\section{(2) OpenEdition}

1 Journals

Édition électronique

URL : http://journals.openedition.org/abstractairanica/33622

DOI : 10.4000/abstractairanica.33622

ISSN : 1961-960X

Éditeur :

CNRS (UMR 7528 Mondes iraniens et indiens), Éditions de l'IFRI

Édition imprimée

Date de publication : 15 mai 2008

ISSN : 0240-8910

Référence électronique

Sāsān Fātemī, «Arbaîn dar Būšehr. 1 CD avec livret de présentation (persan et anglais) rédigé par Fowziye Majd, M.CD-217, Tehrān, Māhūr, 2006. [Arbaiîn à Bushehr] », Abstracta Iranica [En ligne],

Volume 29 | 2008, document 432, mis en ligne le 15 septembre 2008, consulté le 26 septembre 2020.

URL : http://journals.openedition.org/abstractairanica/33622 ; DOI : https://doi.org/10.4000/

abstractairanica.33622

Ce document a été généré automatiquement le 26 septembre 2020.

Tous droits réservés 


\title{
Arba în dar Būšehr. 1 CD avec livret de présentation (persan et anglais) rédigé par Fowziye Majd, M.CD-217, Tehrān, Māhūr, 2006. [Arba'în à Bushehr]
}

\author{
Sāsān Fātemī
}

Encore un autre enregistrement précieux de Fowziye Majd qui date de 1973. Cette fois c'est la voix unique et fascinante du regretté JahānbaȞš Kordīzāde (BaHšsū) et aussi celle de Hoseyn Hormā'ī qu'elle a captées pendant des cérémonies de deuil religieux à Būšehr. Il existe très peu d'enregistrements de BaHš̌u dans les archives et chez les privés et, hormis cet album, aucun enregistrement publié officiellement.

\section{INDEX}

Thèmes : 17.1.Musique

\section{AUTEURS}

\section{SĀSĀN FĀṬEMĪ}

Université de Téhéran 